\section{Going slow on AIDS}

\section{The US General Accounting Office says AIDS must be tackled more energetically.}

THE general belief that the Reagan administration is not sufficiently energetic in its attempts to control the spread of AIDS (acquired immune deficiency syndrome) was last week confirmed by an unexpected source - the agency of government called the General Accounting Office (GAO). Asked on 16 June by the chairman of the Senate subcommittee responsible for appropriations to the Public Health Service for an opinion of the administration's budget proposals, GAO has done what many reporters have been doing these past months, but with commendable thoroughness and speed.

GAO has talked to people familiar with the disease either professionally or as participants in several studies of the consequences of AIDS for the US population that have appeared since last year's joint study by the US Academies of Medicine and of Science (Confronting AIDS, see Nature 324 3 ; 1986). GAO officials have visited cities where AIDS is a serious problem, talking to local public health officials. They have also held discussions with activist groups as well as the Public Health Service itself. All this has been done in just two months. GAO's formal report was delivered on 12 August.

In general, GAO found support for the administration's primary prevention plans - containing the spread of human immunodeficiency virus (HIV) among intravenous drug abusers, educating high-risk groups and the general public, and expanding voluntary testing and counselling. But the investigation also uncovered a consensus that funds for these purposes are far from adequate. Worse, GAO says that the general perception of a lack of federal leadership on AIDS is more worrying than the lack of money.

In the best tradition, GAO has also firmly stepped outside its terms of reference to evaluate the administration's plans and has suggested less costly ways of achieving some of the administration's professed goals. Thus the report suggests that posters on public transportation would be a cheaper and more effective way to spread AIDS education than mailing information to people's home addresses. But GAO's main conclusion is that already reached by many of those familiar with the dangers of AIDS for the public health: education should be the first line of defence against spread of the disease. That was also the clearest line running through Confronting AIDS.

The Reagan administration and the Public Health Service have not yet taken this message to heart. Assistant Secretary of Health Robert Windom, head of the Public Health Service, contends that the government is getting its message across through the news media and in commercial advertising time donated by broadcasters for public service announcements. But the free time is unlikely to be prime time, and it is not the job of the news media to put out government propaganda, no matter how noble its object. Moreover, the administration's budget request for AIDS education, $\$ 155$ million for all activities, does not go far in the hard-sell advertising world.

It is also disingenuous, if not downright irresponsible, for Windom to suggest that the United States government has less need than foreign governments, such as those of the United Kingdom and of Sweden, to warn its people about the dangers of AIDS simply because the cost of treating AIDS patients is not a direct charge on the federal budget. In the United States, health insurance companies will naturally want to be partners in public education campaigns, as they have begun to be in New York state. But can Windom seriously be suggesting that the government abdicate its responsibility for the nation's health to the good will and public spirit of private companies? If so, he is making a mockery of his post as head of the public health service, and undermining the work of his surgeon general and others who are fighting hard to stop the spread of AIDS.
The administration's lassitude in the prevention of the spread of AIDS has many roots. Last year's well-publicized row between the Surgeon-General and the Secretary of Education, $\mathrm{Mr}$ William J. Bennett, may have blown over, but the administration remains shy of giving people explicit advice about their sexual behaviour. A more subtle explanation of its diffidence on AIDS may be that it is trapped by the American conviction that problems arise only so that they can be fixed, preferably by action. Preventive medicine is embodied in the running shoes that impel a large proportion of the population along their local highways every day (sometimes with consequences that are the opposite of those intended), so if AIDS is as grave a threat to the long-term future as the evidence suggests it could be, should it not be met with decisive action of some kind? Can education, slow and necessarily uncertain, be a sufficient remedy? Patient perseverance, even when it is the only policy, is always a tough row for the White House to hoe. When President Reagan and his cohorts in the White House were frustrated by the delay in freeing US hostages in Beirut, they took action even though it was a bizarre contradiction of their declared policy of not bargaining with hostage-takers; are they not likely to be seduced by the notion that'victory against AIDS will be won by armies of researchers armed with the mighty weapons of molecular biology rather than by the slow process of modifying behaviour, mostly sexual? What the US government needs to do is somehow to persuade its constituents that there will be no quick win for AIDS, but a lifetime's need for care and vigilance. And the sooner it begins, the sooner it will begin to dent the problem.

\section{A monsoon failure}

\section{This year's failure of the Indian summer mon- soon is not as tragic as it once would have been.}

THERE are two views of the failure of this year's summer monsoon in India. One is that the unhappy outcome of this year's seasonal roulette is but a familiar part of India's history. Inevitably, the years in which the June skies do not burst are years of tragedy. As always, India's poor will suffer most, especially in those regions not yet transformed by the tube-well and the green revolution, but there will be hardship even in the prosperous Punjab. More probably, many in India will be confirmed in the old fatalistic belief that they can do nothing against the great seasonal catastrophes, of which the failure of the monsoon is merely the most serious in the calendar.

That is the bad news. The good news is that India has been able to build up a stock of 23 million tonnes of grain over the past years of plenty, perhaps a third of annual consumption. With good management and the likelihood that irrigated areas will still produce a substantial part of their yield in a good year, India should be able to avoid, with its own resources, the widespread famines that followed the past failures of the monsoon. Much will depend on the care with which the available grain can be shared out among those most in need of it; corruption and the selfishness of state governments will be a nuisance. India may also emerge as a buyer on the world's grain markets, but need not on this occasion be a beggar.

There are several lessons to be learned. In India, where the prime minister, Mr Rajiv Gandhi, is the chairman of the committee set up to deal with the emergency, the government will rightly conclude that, for the long run, it had better follow even more energetically than in the past its policies for making India fertile. People in India and elsewhere who believe that the green revolution is simply a ramp for turning honest peasants into greedy farmers will at least be given pause. Other countries in which near-famine is almost a way of life may be persuaded to rethink their policies on agriculture. It is even possible that a monsoon failure that does not lead to utter catastrophe may serve to exorcise India's incubus of superstition, born of the conviction that there are no deals to be made with nature. 